\title{
Larval habitat characteristics of the main malaria vectors in the most endemic regions of Colombia: potential implications for larval control
}

\author{
Marcela Conde ${ }^{1}$, Paula X. Pareja², Lorena I. Orjuela², Martha L. Ahumada², Sebastian Durán ${ }^{2}$, Jennifer A. Jara ${ }^{3}$,
} Braian A. Cañon ${ }^{3}$, Pilar Pérez ${ }^{4}$, John C. Beier ${ }^{5}$, Socrates Herrera ${ }^{6}$ and Martha L. Quiñones ${ }^{1 *}$ (D)

\begin{abstract}
Background: Malaria incidence has recently decreased globally and, as malaria elimination is envisioned as a possibility by the health authorities, guidance is needed to strengthen malaria control strategies. Larval source treatment, which could complement routine vector control strategies, requires knowledge regarding the Anopheles larval habitats.

Methods: A cross-sectional study was conducted in three of the most malaria-endemic regions in Colombia. A total of 1116 potential larval habitats in 70 villages were sampled in three states located in western Colombia: Cordoba, Valle del Cauca and Nariño.

Results: Overall, $17.5 \%$ (195) of the potential larval habitats were found positive for different Anopheles species. A total of 1683 larvae were identified belonging to seven species: Anopheles albimanus, Anopheles calderoni, Anopheles darlingi, Anopheles neomaculipalpus, Anopheles nuneztovari s.l., Anopheles pseudopunctipennis, and Anopheles triannulatus. The most widely distributed species was An. nuneztovari s.l., which was found mainly in human-made fishponds in Cordoba and temporary puddles in Valle del Cauca. Anopheles albimanus and An. calderoni were associated with human-made wells or excavation sites in Nariño. Cordoba displayed the greatest Anopheles species diversity with a total of six species (Shannon diversity index $H^{\prime}:$ 1.063). Although Valle del Cauca had four species, one more than Nariño, the diversity was lower because only one species predominated, An. nuneztovari s.l. The larval habitats with the highest Shannon diversity index were lagoons ( $H^{\prime}$ : 1.079) and fishponds ( $\left.H^{\prime}: 1.009\right)$ in Cordoba, excavation sites in Nariño ( $\left.H^{\prime}: 0.620\right)$ and puddles in Valle del Cauca ( $\left.H^{\prime}: 0.764\right)$.
\end{abstract}

Conclusions: This study provides important information regarding the larval habitats of the main malaria vectors in the most malaria-endemic regions of Colombia, which will be useful in guiding larval control operations.

Keywords: Anopheles, Larval habitats, Malaria, Latin America

\section{Background}

Between 2000 and 2013 global malaria incidence and mortality rates decreased 30 and $47 \%$, respectively, based on the estimated number of cases for every 1000 persons

\footnotetext{
*Correspondence: mlquinonesp@unal.edu.co

${ }^{1}$ Departamento de Salud Pública, Facultad de Medicina, Universidad

Nacional de Colombia, Bogotá, DC, Colombia

Full list of author information is available at the end of the article
}

[1]. If this trend continues, it is estimated that global malaria incidence may decrease up to $35 \%$ by the end of 2015. In the Americas, malaria cases have decreased from 1.2 million cases in 2000 to 427,000 cases in 2013 $(64 \%)$ and mortality decreased by $79 \%$ for the same period. Based on the incidence of cases reported for those years, it is predicted that by the end of 2015 a total of 15 endemic countries in the region will have reached a 
reduction of $75 \%$ and three other countries a reduction between 50 and $75 \%$ [1].

The majority of countries in Latin America are moving toward malaria elimination. Argentina has reported no cases since 2013 and other countries, such as Costa Rica and El Salvador, reported less than ten cases per year. Ten Central American and Caribbean countries (Belize, Costa Rica, Dominican Republic, El Salvador, Guatemala, Haiti, Honduras, Mexico, Nicaragua, and Panama) have joined the regional initiative towards Malaria Elimination in Mesoamerica and Hispaniola (EMMIE) in 2020 [2] as well as the Malaria Certification in the Americas Region by 2025 supported by the Global Fund for AIDS, Tuberculosis and Malaria (GFATM) [2, 3]. In addition, countries in South America, such as Argentina and Paraguay, are also supporting efforts toward malaria elimination [1, 4].

The 21 countries considered at risk for malaria transmission in the Americas have adopted policies of malaria vector control using indoor residual spraying (IRS) and/or long lasting insecticide-treated mosquito nets (LLINs) in specific areas of continuous transmission [1]. These measures primarily affect endophagic and endophilic behaviour leaving mosquitoes with exophagic and exophilic behaviour with ample opportunity to bite without coming into contact with treated surfaces. Transmission caused by mosquito bites outdoors and before a community retires to sleep is known as 'residual transmission' [5]. In Colombia between 40 and 47 Anopheles species have been found [6], from which ten have been incriminated as malaria vectors: Anopheles darlingi, Anopheles albimanus, Anopheles nuneztovari s.l, Anopheles neivai, Anopheles punctimacula, Anopheles pseudopunctipennis, Anopheles pholidotus (as Anopheles lepidotus) [7], Anopheles calderoni [8], Anopheles rangeli, and Anopheles oswaldoi [9]. All vectors exhibit a tendency to bite more outdoors than indoors, and rest outdoors $[8,10-13]$. This behaviour has been considered a major obstacle for malaria control in many countries of the Americas in which IRS is the main control measure [14].

Currently, there is a need to adopt additional strategies that will impact the Anopheles species with partially exophagic and exophilic habits in order to reduce the incidence of malaria in Latin America countries and to reach the pre-elimination and elimination phases, and thus, treatment of potential larval habitats could be considered an additional strategy [15].

The use of larvicides and biological control has been shown to be effective for the control of malaria globally [16]. The use of larvivorous nematode species, such as Romanomermis culicivorax, bacterial preparations based on Bacillus thuringiensis variety israelensis (Bti) and
Bacillus sphaericus (Bsph) have been shown to be highly effective against African and Latin America malaria vectors, reducing larvae densities by up to $90 \%$, and showed even reduction in malaria prevalence in schoolchildren [17-21]. An alternative is the introduction of larvivorous fish of the species Oreochromis spirulus, which has been shown that to reduce Anopheles spp. larval density. However, more studies to examine effects on malaria in humans and on the entomological inoculation rate or at least the density of adult vector mosquitoes will be necessary $[22,23]$.

The most important malaria control measures are directed towards mosquitoes inside homes. However, in Latin America a great proportion of human-vector contact occurs outdoors [14, 24]. The objective of this study was to increase the knowledge regarding larval habitats in endemic populations in order to determine the feasibility of treating larval habitats, to diminish humanvector contact and contribute towards efforts for malaria elimination in the region.

\section{Methods \\ Study area}

The study took place in three of the states with the highest malaria transmission in Colombia: Córdoba (northwestern region of the country), Nariño and Valle del Cauca (both in the western region on the Pacific coast). In general, all areas follow an endemic-epidemic [25] and perennial pattern of transmission [26]. Between them a distinctive predominance of Plasmodium species is found. In Córdoba, 70 \% of malaria infections are caused by Plasmodium vivax and $30 \%$ by Plasmodium falciparum, while on the Pacific coast, the P. vivax/P. falciparum ratio is reversed with $P$. falciparum as the predominant parasite [25]. In total, 70 localities were selected for a cross-sectional study: 27 in Cordoba, 21 in Valle del Cauca and 22 in Nariño. The selection criteria included localities with high malaria incidence, easy access by land or river, and safety (Fig. 1).

The localities selected in Córdoba are in an area with northern latitudes between $07^{\circ} 53^{\prime} 53^{\prime \prime}$ and $08^{\circ} 15^{\prime} 41^{\prime \prime}$, and western longitudes between $75^{\circ} 25^{\prime} 30^{\prime \prime}$ and $76^{\circ} 08^{\prime} 49^{\prime \prime}$. Most of the localities are hilly. The annual average rainfall is between 1525 and $2333 \mathrm{~mm}$ and the annual average temperature between 26.4 and $28{ }^{\circ} \mathrm{C}$ depending on the altitude. The most important economic activities are based on livestock, agriculture (mainly maize, cassava, sorghum, rice, banana crops), forestry, and mining of gold and silver [27]. The localities selected in Nariño and Valle del Cauca are located in an area with northern latitudes between $01^{\circ} 47^{\prime} 55^{\prime \prime}$ and $03^{\circ} 53^{\prime} 36^{\prime \prime}$ and western longitudes between $77^{\circ} 04^{\prime} 11^{\prime \prime}$ and $78^{\circ} 48^{\prime} 56^{\prime \prime}$. Most of the localities are flat to slightly undulating. The annual 


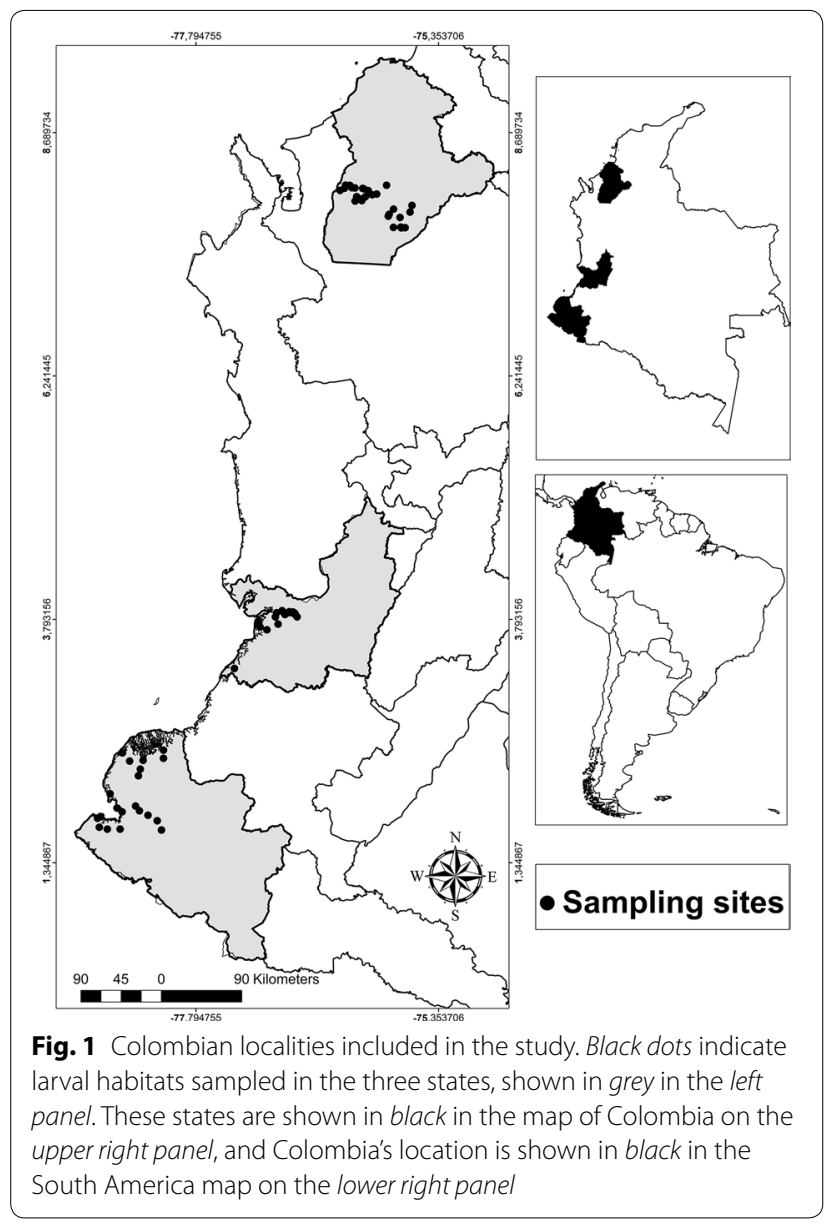

average rainfall is between 2,191 and $6,980 \mathrm{~mm}$ and the annual average temperature between 25.8 and $27^{\circ} \mathrm{C}$. The most important economic activities are based on fishing, with some mining and agriculture (mainly banana, blackberry, cocoa, other local fruits) [27].

\section{Larval habitat characterization}

Larval specimen collections were carried out in each of the 70 localities with data collection between May 2011 and November 2012. Each locality was visited for 1 week each during which all potential larval habitats present within a $1-\mathrm{km}$ radius of the houses were sampled once for anopheline larvae between the hours of 08:00 and 12:00. The larval habitats were characterized and classified according to their distance to the nearest house, stability (temporary or permanent habitats), presence of vegetation, water flow (stagnant water or with movement), water clarity (clear or turbid), use (drainage, swimming pool, animal, domestic, none) and type defined as excavation site (a hole made by removing material), fishpond (pond or artificial lake used for fish farming), lagoon (a body of fresh water of considerable size, surrounded by land), stream (a body of water flowing in a channel, as a brook), puddle (a small pool of water, as of rainwater on the ground), ditch (a long, narrow channel dug in the ground, such as for drainage or irrigation, trench), bromeliad (epiphytic tropical American plants, having long, stiff leaves and showy flowers) or other.

\section{Larval sampling}

In each potential habitat larval sampling was done using the standard dipping method with a 400-ml ladle with ten samples per sq $\mathrm{m}$ [28]. Collected larvae were maintained for linked rearing and the larval and pupal skins kept for taxonomic determination [29]. A portion of the late instars were immediately preserved in $70 \%$ ethanol and taken to the Medical Entomology Laboratory of the Instituto Nacional de Salud of Colombia in Bogota. Species of mosquito larvae were determined using the most recent Colombian morphological Anopheles key [30].

\section{Data analysis}

In order to analyse the stability of the different types of positive larval habitats for Anopheles larvae by state, contrast homogeneity was performed on qualitative variables using RWizard 1.0 (R 3.1.2, The R Project for Statistical Computing). A multiple correspondence analysis (MCA) was used (using $\mathrm{R}$ software version 3.2.0, packages ade4 and FactoMineR) to describe the main characteristics associated with each Anopheles species larval habitats. The categorical variables included were: stability, type, presence of vegetation, water flow, clarity of water, and use. The Fager's affinity index (IFM) [31] was calculated to determine the association between the different anopheline species occurring in the same breeding site according to the following expression: IFM: $J / \sqrt{ } \mathrm{N}_{A} \mathrm{~N}_{B}-1 / 2 \sqrt{ } \mathrm{N}_{\mathrm{B}}$, where $J$ is the number of co-occurrences, $\mathrm{N}_{\mathrm{A}}$ is the total number of occurrences of species $A$ alone, $N_{B}$ is the total number of occurrences of species $B$ alone and species are chosen such that $\mathrm{N}_{\mathrm{A}} \leq \mathrm{N}_{\mathrm{B}}$. The resulting value provides a quantitative measure of species association. A value $\geq 0.5$ is indicative of affinity. To analyse the interactions between Anopheles species and larval habitats, networks of interaction were constructed using the $\mathrm{R}$ statistical software (R Development Core Team 2007). In this model, the abundance and diversity of species by larval habitat were evaluated. Shannon's diversity index $\left(\mathrm{H}^{\prime}\right)$ was used to characterize species diversity in each state to show the abundance and evenness of the species present in the different larval habitats according to the following expression: $\mathrm{H}^{\prime}: \Sigma((\mathrm{Pi}) \times \operatorname{Ln}(\mathrm{Pi}))$, where $\mathrm{Pi}$ is number of individuals of species/total number of samples [32]. Analysis of variance (ANOVA) was used to evaluated the distance between the inspected and positive sites and the nearest houses for each area of study. 


\section{Results}

A total of 1,116 potential larval habitats were inspected in the three states, $17.5 \%$ (195) of which were found positive for different Anopheles species. The state with the highest number of potential larval habitat sites inspected was Valle del Cauca (700), followed by Nariño (242) and then Córdoba (174). Cordoba was the state with the highest proportion of positive larval habitats (37.4 \%) (Table 1).

A total of 1683 larvae were identified belonging to seven species. These species were An. albimanus, $A n$. calderoni, An. darlingi, An. neomaculipalpus, An. nuneztovari s.l., An. pseudopunctipennis and An. triannulatus (Table 1). Cordoba was the state with the highest diversity of Anopheles species (six) (Shannon diversity index $\mathrm{H}^{\prime}$ : 1.063). Although Valle del Cauca had four species, one more than Nariño, the Shannon diversity index was lowest as one species, An. nuneztovari s.l., predominated. The breeding site types with the highest Shannon diversity index were lagoons $\left(\mathrm{H}^{\prime}: 1.079\right)$ and fishponds $\left(\mathrm{H}^{\prime}:\right.$ 1.009) in Cordoba, excavation sites in Nariño $\left(\mathrm{H}^{\prime}\right.$ : 0.620) and puddles in Valle del Cauca $\left(\mathrm{H}^{\prime}\right.$ : 0.764). In Cordoba, the fishponds had a higher number of Anopheles species than lagoons; the diversity in fishponds was lower because An. triannulatus and An. nuneztovari s.l. were predominant in this type of habitat (Table 2).

Table 3 shows the characteristics of mosquito larval habitats such as vegetation presence, water flow, water clarity, stability, habitat types, and uses. The most common larval habitat types found were excavation sites, fishponds, bromeliads, streams, pools, ditches, and lagoons (Fig. 2a-f).

In Cordoba, An. nuneztovari s.l. larvae were found in larval habitats characterized by having vegetation, stagnant water and clear water (Fig. 3a). Anopheles triannulatus were found in fishponds used for commercial rearing of fish, the majority of which were permanent; these larval habitats had vegetation, turbid and stagnant water (Fig. 3b). Larvae of An. albimanus were found in larval habitats that were permanent, characterized by having vegetation, turbid and stagnant water (Fig. 3c). In Nariño, An. albimanus were found in puddles and excavation sites used for domestic activities, such as washing dishes, cleaning floors and even cooking, the majority of which were temporal. These larval habitats had stagnant water and vegetation (Fig. 4a). Larvae of $A n$. calderoni were present in excavation sites used for domestic activities. These larval habitats were characterized by being permanent, having vegetation and stagnant water (Fig. 4b). In Valle del Cauca, the presence of An. nuneztovari s.l. was associated with permanent larval habitats with stagnant water and vegetation (Fig. 5a). Finally, An. pseudopunctipennis were found in fishponds and puddles without use, the majority of which were permanent. These larval habitats had stagnant water and vegetation (Fig. 5b). The type and use of larval habitats showed association in most cases, i.e., fishponds were used for rearing fish, puddles had no use, excavations were mainly used for domestic purposes, etc.; therefore, the MCA considered the variable type only to avoid redundancy for autocorrelation.

The analysis of contrast homogeneity for qualitative variables showed significant differences regarding the stability of the larval habitats; fishponds in Cordoba and excavation sites in Nariño were associated with permanent larval habitats, while in Valle del Cauca the puddles were associated with being temporary compared to other types of larval habitats inspected (Fig. 6).

Table 1 Larval habitats inspected, larvae presence (positive for larvae) and number of larvae of the different Anopheles species found in each study site

\begin{tabular}{|c|c|c|c|c|c|c|c|c|c|c|c|}
\hline \multirow[t]{2}{*}{ State } & \multirow{2}{*}{$\begin{array}{l}\text { Number } \\
\text { of larval } \\
\text { habitats } \\
\text { sampled }\end{array}$} & \multirow[t]{2}{*}{ Positive } & \multirow[t]{2}{*}{$\begin{array}{l}\% \text { Posi- } \\
\text { tive }\end{array}$} & \multirow[t]{2}{*}{$\begin{array}{l}\text { Larvae } \\
\text { (n) }\end{array}$} & \multicolumn{7}{|c|}{$\begin{array}{l}\% \text { Larval habitats positive for Anopheles species (number of larval habitats positive } \\
\text { for each specie/total positive habitats) }\end{array}$} \\
\hline & & & & & $\begin{array}{l}\text { An. albi- } \\
\text { manus }\end{array}$ & $\begin{array}{l}\text { An. nunez- } \\
\text { tovari s.l. }\end{array}$ & $\begin{array}{l}\text { An. dar- } \\
\text { lingi }\end{array}$ & $\begin{array}{l}\text { An. trian- } \\
\text { nulatus }\end{array}$ & $\begin{array}{l}\text { An.pseu- } \\
\text { dopuncti- } \\
\text { pennis }\end{array}$ & $\begin{array}{l}\text { An. calde- } \\
\text { roni }\end{array}$ & $\begin{array}{l}\text { An. neo- } \\
\text { maculipal- } \\
\text { pus }\end{array}$ \\
\hline $\begin{array}{l}\text { Cordoba } \\
\text { (a) }\end{array}$ & 174 & 65 & 37.4 & 439 & $17(11 / 62)$ & $55(36 / 62)$ & $3(2 / 62)$ & $55(36 / 62)$ & $2(1 / 62)$ & & $8(5 / 62)$ \\
\hline Nariño (b) & 242 & 42 & 17.4 & 333 & $81(34 / 42)$ & & & & & $29(12 / 42)$ & $2(1 / 42)$ \\
\hline $\begin{array}{l}\text { Valle del } \\
\text { Cauca } \\
\text { (c) }\end{array}$ & 700 & 88 & 12.6 & 911 & $1(1 / 88)$ & $88(77 / 88)$ & & & $17(15 / 88)$ & & $8(7 / 88)$ \\
\hline Overall & 1116 & 195 & 17.5 & 1683 & & & & & & & \\
\hline
\end{tabular}

The larval habitats were sampled once in different months of the year. Sampling months: (a) April-November 2012, (b) May-September 2011 and April-September 2012, (c) April-September 2012 
Table 2 Shannon diversity indices $\left(\mathrm{H}^{\prime}\right)$ of Anopheles species in different types of larval habitats in each state studied

\begin{tabular}{|c|c|c|c|c|c|c|c|c|}
\hline $\begin{array}{l}\text { State } \\
\text { (no. larvae } \\
\text { found) }\end{array}$ & $\begin{array}{l}\text { Type of larval } \\
\text { habitat }\end{array}$ & Species & No. larvae & Proportion $(\mathrm{Pi})^{\mathrm{a}}$ & Loge $\mathrm{Pi}$ & Pi Loge Pi & $\begin{array}{l}\mathrm{H}^{\prime} \text { by type } \\
\text { of larval habitat }\end{array}$ & $\begin{array}{l}\mathrm{H}^{\prime} \text { by } \\
\text { state }\end{array}$ \\
\hline \multirow[t]{22}{*}{ Córdoba (439) } & \multirow[t]{4}{*}{ Excavation site } & An.nuneztovari s.l. & 5 & 0.119 & -2.128 & -0.253 & \multirow[t]{4}{*}{0.583} & \multirow[t]{4}{*}{1.06} \\
\hline & & An.darlingi & 1 & 0.024 & -3.738 & -0.089 & & \\
\hline & & An. triannulatus & 35 & 0.833 & -0.182 & -0.152 & & \\
\hline & & An. neomaculipalpus & 1 & 0.024 & -3.738 & -0.089 & & \\
\hline & \multirow[t]{6}{*}{ Fishpond } & An. albimanus & 22 & 0.071 & -2.639 & -0.189 & \multirow[t]{6}{*}{1.009} & \\
\hline & & An. nuneztovari s.l. & 125 & 0.406 & -0.902 & -0.366 & & \\
\hline & & An. darlingi & 4 & 0.013 & -4.344 & -0.056 & & \\
\hline & & An. triannulatus & 154 & 0.500 & -0.693 & -0.347 & & \\
\hline & & An.pseudopunctipennis & 2 & 0.006 & -5.037 & -0.033 & & \\
\hline & & An. neomaculipalpus & 1 & 0.003 & -5.730 & -0.019 & & \\
\hline & \multirow[t]{3}{*}{ Lagoon } & An. albimanus & 2 & 0.286 & -1.253 & -0.358 & \multirow[t]{3}{*}{1.079} & \\
\hline & & An. nuneztovari s.l. & 2 & 0.286 & -1.253 & -0.358 & & \\
\hline & & An. triannulatus & 3 & 0.429 & -0.847 & -0.363 & & \\
\hline & \multirow[t]{2}{*}{ Stream } & An. nuneztovari s.l. & 3 & 0.750 & -0.288 & -0.216 & \multirow[t]{2}{*}{0.562} & \\
\hline & & An. triannulatus & 1 & 0.250 & -1.386 & -0.347 & & \\
\hline & \multirow[t]{4}{*}{ Puddle } & An. albimanus & 8 & 0.118 & -2.140 & -0.252 & \multirow[t]{4}{*}{0.894} & \\
\hline & & An. nuneztovari s.l. & 49 & 0.721 & -0.328 & -0.236 & & \\
\hline & & An. triannulatus & 6 & 0.088 & -2.428 & -0.214 & & \\
\hline & & An. neomaculipalpus & 5 & 0.074 & -2.610 & -0.192 & & \\
\hline & Ditch & An. albimanus & 3 & 1.000 & 0.000 & 0.000 & 0.000 & \\
\hline & \multirow[t]{2}{*}{ Other } & An. nuneztovari s.l. & 1 & 0.143 & -1.946 & -0.278 & \multirow[t]{2}{*}{0.410} & \\
\hline & & An. triannulatus & 6 & 0.857 & -0.154 & -0.132 & & \\
\hline \multirow[t]{8}{*}{ Nariño (333) } & \multirow[t]{2}{*}{ Excavation site } & An. albimanus & 95 & 0.688 & -0.373 & -0.257 & \multirow[t]{2}{*}{0.620} & \multirow[t]{8}{*}{0.432} \\
\hline & & An. calderoni & 43 & 0.312 & -1.166 & -0.363 & & \\
\hline & Lagoon & An. neomaculipalpus & 1 & 1.000 & 0.000 & 0.000 & 0.000 & \\
\hline & \multirow[t]{2}{*}{ Puddle } & An. albimanus & 128 & 0.985 & -0.016 & -0.015 & \multirow[t]{2}{*}{0.079} & \\
\hline & & An. calderoni & 2 & 0.015 & -4.174 & -0.064 & & \\
\hline & Ditch & An. albimanus & 22 & 1.000 & 0.000 & 0.000 & 0.000 & \\
\hline & \multirow[t]{2}{*}{ Other } & An. albimanus & 39 & 0.929 & -0.074 & -0.069 & \multirow[t]{2}{*}{0.257} & \\
\hline & & An. calderoni & 3 & 0.071 & -2.639 & -0.189 & & \\
\hline Valle del Cauca (911) & Excavation site & An. nuneztovari s.l. & 98 & 0.970 & -0.030 & -0.029 & 0.134 & 0.399 \\
\hline & & An.pseudopunctipennis & 3 & 0.030 & -3.517 & -0.104 & & \\
\hline & Fishpond & An. nuneztovari s.l. & 431 & 0.995 & -0.005 & -0.005 & 0.029 & \\
\hline & & $\begin{array}{l}\text { An. pseudopuncti- } \\
\text { pennis }\end{array}$ & 2 & 0.005 & -5.378 & -0.025 & & \\
\hline & Lagoon & An. neomaculipalpus & 4 & 1.000 & 0.000 & 0.000 & 0.000 & \\
\hline & Stream & An. nuneztovari s.l. & 80 & 0.889 & -0.118 & -0.105 & 0.349 & \\
\hline & & An.pseudopunctipennis & 10 & 0.111 & -2.197 & -0.244 & & \\
\hline & Puddle & An.albimanus & 1 & 0.004 & -5.537 & -0.022 & 0.764 & \\
\hline & & An. nuneztovari s.l. & 189 & 0.744 & -0.296 & -0.220 & & \\
\hline & & An.pseudopunctipennis & 31 & 0.122 & -2.103 & -0.257 & & \\
\hline & & An. neomaculipalpus & 33 & 0.130 & -2.041 & -0.265 & & \\
\hline & Ditch & An.pseudopunctipennis & 4 & 1.000 & 0.000 & 0.000 & 0.000 & \\
\hline & Other & An. nuneztovari s.l. & 22 & 0.880 & -0.128 & -0.112 & 0.367 & \\
\hline & & An. neomaculipalpus & 3 & 0.120 & -2.120 & -0.254 & & \\
\hline
\end{tabular}

The larval habitats were sampled once in different months of the year

a Proportion: number of individuals of species/total number collected in each type of larval habitat 
Table 3 Characteristics of larval habitats for Anopheles species in Cordoba, Valle del Cauca and Nariño

\begin{tabular}{|c|c|c|c|c|c|c|c|c|c|c|}
\hline \multirow{2}{*}{\multicolumn{2}{|c|}{$\begin{array}{l}\text { Characteristic of larval } \\
\text { habitats }\end{array}$}} & \multicolumn{4}{|l|}{ Cordoba } & \multicolumn{2}{|l|}{ Nariño } & \multicolumn{3}{|c|}{ Valle del Cauca } \\
\hline & & $\begin{array}{l}\% A B M \\
n=15\end{array}$ & $\begin{array}{l}\% \text { NTV } \\
n=41\end{array}$ & $\begin{array}{l}\% \text { TRI } \\
n=37\end{array}$ & $\begin{array}{l}\% \text { NEO } \\
n=5\end{array}$ & $\begin{array}{l}\% \text { ABM } \\
n=34\end{array}$ & $\begin{array}{l}\% \text { CAL } \\
n=12\end{array}$ & $\begin{array}{l}\% \text { NTV } \\
n=77\end{array}$ & $\begin{array}{l}\% \text { PPP } \\
n=15\end{array}$ & $\begin{array}{l}\% \text { NEO } \\
n=7\end{array}$ \\
\hline \multirow[t]{2}{*}{ Stability } & Temporary & 27.3 & 22.2 & 5.6 & 60 & 30.3 & 16.7 & 28.6 & 33.3 & 28.6 \\
\hline & Permanent & 77.7 & 77.8 & 94.4 & 40 & 69.7 & 83.3 & 71.4 & 66.7 & 71.4 \\
\hline \multirow[t]{7}{*}{ Type } & $\begin{array}{l}\text { Excavation } \\
\text { site }\end{array}$ & - & 8.6 & 11.4 & 20 & 69.7 & 75 & 16.9 & 6.7 & - \\
\hline & Fishpond & 45.5 & 60 & 71.4 & 20 & - & - & 27.3 & 13.3 & - \\
\hline & Lagoon & 9.1 & 2.9 & 2.9 & - & - & - & - & - & 14.3 \\
\hline & Stream & - & 2.9 & 2.9 & - & - & - & 6.5 & 26.7 & - \\
\hline & Puddle & 36.4 & 22.9 & 5.7 & 60 & 24.2 & 16.7 & 46.8 & 46.7 & 71.4 \\
\hline & Ditch & 9.1 & - & - & - & 3 & - & - & 6.7 & - \\
\hline & Other & - & 2.9 & 5.7 & - & 3 & 8.3 & 2.6 & - & 14.3 \\
\hline \multirow[t]{2}{*}{ Vegetation } & Present & 100 & 100 & 100 & 100 & 95.9 & 88.2 & 96.6 & 100 & 92.9 \\
\hline & Absent & - & - & - & - & 4.1 & 11.8 & 3.4 & - & 7.1 \\
\hline \multirow[t]{2}{*}{ Water flow } & $\begin{array}{l}\text { Stagnant } \\
\text { water }\end{array}$ & 100 & 97.2 & 94.4 & 100 & 97.1 & 100 & 93.5 & 73.3 & 100 \\
\hline & $\begin{array}{l}\text { With move- } \\
\text { ment }\end{array}$ & - & 2.8 & 5.6 & - & 2.9 & - & 6.5 & 26.7 & - \\
\hline \multirow{2}{*}{$\begin{array}{l}\text { Water } \\
\text { clarity }\end{array}$} & Clear & 18.2 & 11.1 & 11.4 & - & 72.7 & 75 & 51.9 & 73.3 & 57.1 \\
\hline & Turbid & 81.8 & 88.9 & 88.6 & 100 & 27.3 & 25 & 48.1 & 26.7 & 42.9 \\
\hline \multirow[t]{5}{*}{ Use } & Drainage & 16.7 & - & 3.4 & - & 3.2 & - & - & 6.7 & - \\
\hline & $\begin{array}{l}\text { Swimming } \\
\text { pool }\end{array}$ & - & - & - & - & - & - & 1.3 & - & 14.3 \\
\hline & Animal & 83.3 & 90.9 & 86.2 & 50 & - & - & 27.3 & 13.3 & \\
\hline & Domestic & - & 4.5 & 3.4 & - & 35.5 & 45.5 & - & - & - \\
\hline & None & - & 4.5 & 6.9 & 50 & 61.3 & 54.5 & 71.4 & 80 & 85.7 \\
\hline
\end{tabular}

ABM: An. albimanus, NTV: An. nuneztovari s.l., DAR: An. darlingi, TRI: An. triannulatus, PPP: An. pseudopunctipennis, NEO: An. neomaculipalpus, CAL: An. calderoni

The larval habitats were sampled once in different months of the year

Results from the interaction network analysis showed that in Cordoba An. triannulatus, An. neomaculipalpus, An. nuneztovari s.l., and An. albimanus shared some larval habitats and that the highest abundance was found for An. nuneztovari s.l. and An. triannulatus (Fig. 7a). In Nariño, An. albimanus was the species with the highest abundance in the localities inspected and An. calderoni shared larval habitats with An. albimanus (Fig. 7b). In Valle del Cauca, An. nuneztovari s.l. showed the highest abundance and shared larval habitats with An. pseudopunctipennis (Fig. 7c).

Only An. nuneztovari s.l. and An. neomaculipalpus showed a significant IFM (0.67) and shared larval habitats in Cordoba state. The other species, although also sharing larval habitats, showed an association that was not significant (Table 4). Anopheles neomaculipalpus in Nariño and An. albimanus in Valle del Cauca did not share any larval habitats with others species.

Compared to Anopheles-negative larval habitats, Anopheles-positive larval habitats were further from the houses, although this difference was only significant in
Valle del Cauca (Table 5). A significant difference was also found between states regarding the distance between houses and positive larval habitats $(\mathrm{F}=30.8 ; \mathrm{p}<0.001)$; the closest proximity between houses and larval habitats was in Nariño (mean distance $=22.7 \mathrm{~m}$ ), followed by those in Cordoba ( $57.2 \mathrm{~m}$ ), and the greatest mean distance was in Valle del Cauca $(205.7 \mathrm{~m})$.

\section{Discussion}

Larval habitats found in the most malaria-endemic regions in Colombia were characterized in a cross-sectional study, regarding their physical description, association between the different anopheline species, species diversity and distance between positive sites and the nearest houses for each area of study, in order to determine the feasibility of treating larval habitats to diminish human vector contact and contribute toward efforts for malaria elimination in the region. The main larval habitats found were permanent and human-made, such a fishponds and excavations for domestic use, which can be treated. Fishponds were the most abundant and positive for An. nuneztovari s.l. larvae 

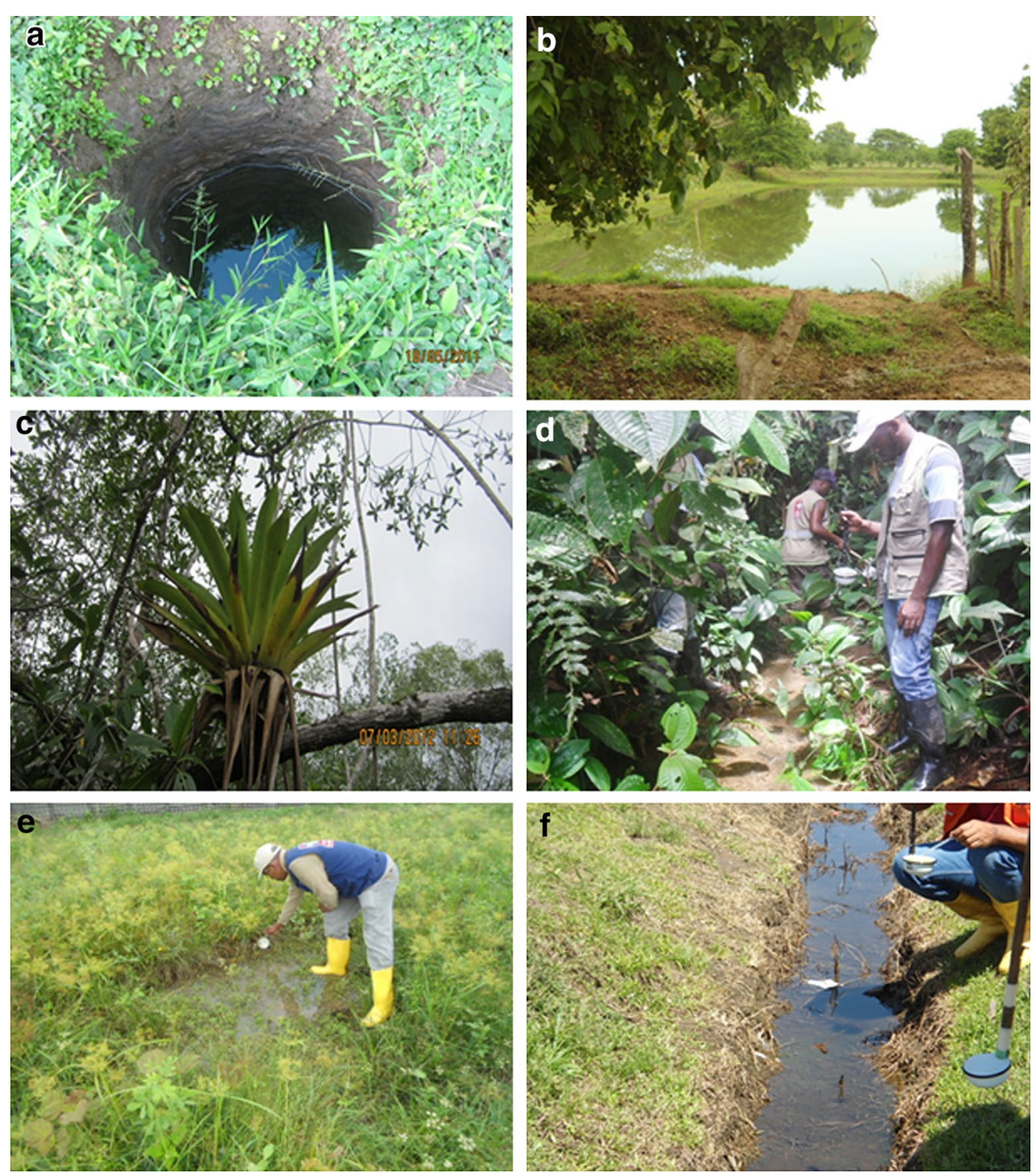

Fig. 2 Larval habitats inspected for Anopheles larvae in Cordoba, Valle del Cauca and Nariño between 2011 and 2012. a Excavation sites, b fishponds, c bromeliads, $\mathbf{d}$ streams, e puddles, $\mathbf{f}$ ditches

in the northwest (state of Cordoba), whereas wells were the main larval habitats for An. albimanus in the southwest in Nariño. In contrast, temporary puddles were the main larval habitats for An. nuneztovari s.l. in Valle del Cauca, which are likely rain-dependent. The WHO recognizes that the treatment of potential larval habitats can be considered an additional strategy for the control of malaria in areas where these are few, identifiable and easy to access [15], which is the case for both permanent human-made types of larval habitats found in this study: fishponds and wells or excavation sites. These larval habitats could be targeted for treatment according to WHO guidelines [15].
The presence of fishponds has been recognized as a serious threat for malaria transmission in other Latin America countries, such as Peru [33] and Brazil [34], where the presence and number of fishponds has been associated with an increase in malaria cases. In those countries, An. darlingi, the most important neotropical malaria vector, seems to have adapted well to fishponds despite predation by fish juveniles [35, 36]. In the IquitosNauta Road in the Peruvian Amazons, there was a higher number of self-reported malaria episodes in households located closer to fishponds, the most commonly positive larval habitats in this area [26]. In the same area, 
Sonde et al. Malar J (2015) 14:476

Page 8 of 14


Fig. 3 Multiple correspondence analysis (MCA) with the main characteristics associated with Anopheles larval habitats in Cordoba. a An. nuneztovari s.l., b An. triannulatus, c An. albimanus. *The larval habitats were sampled once in different months of the year 


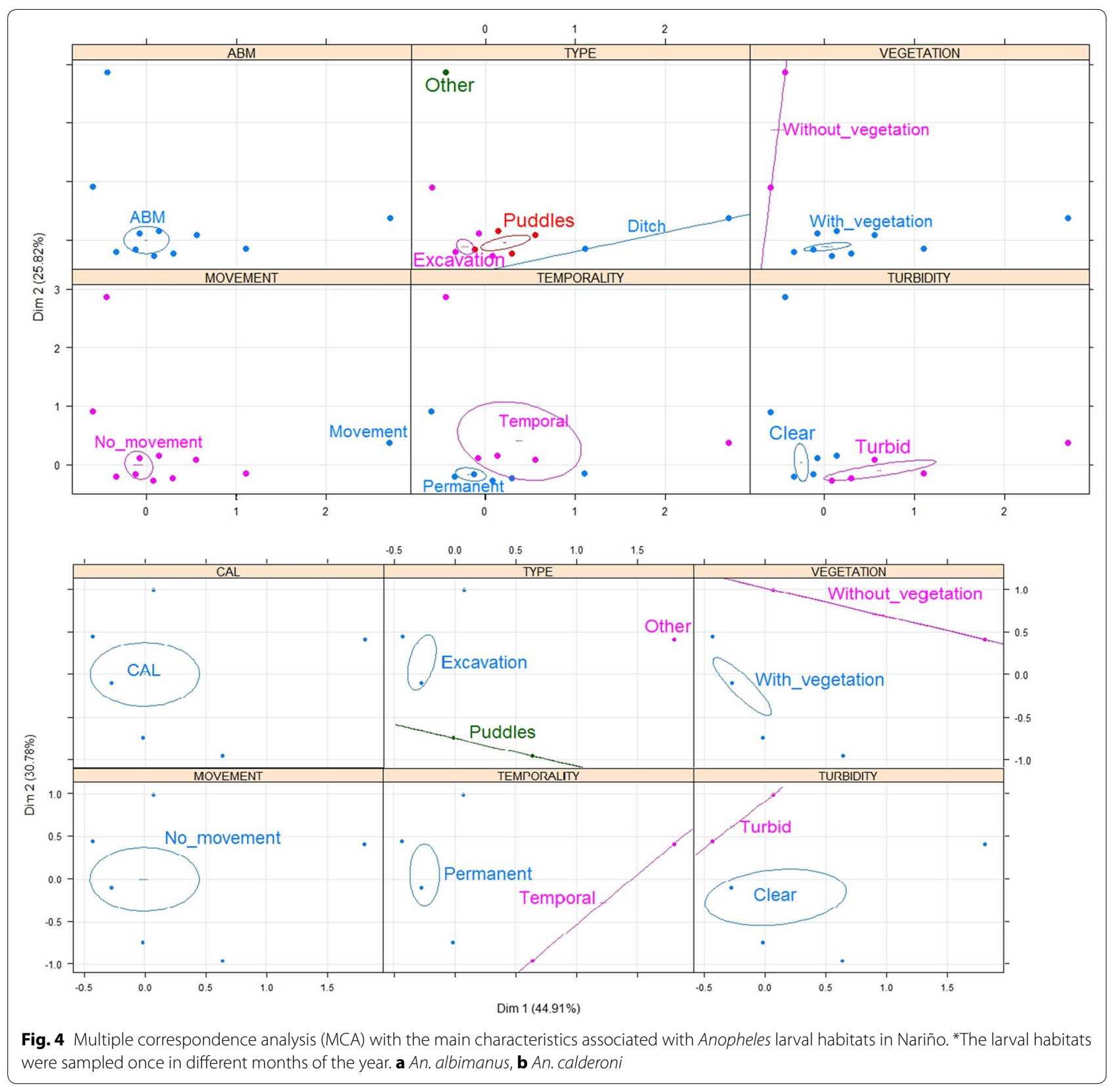

Maheu-Giroux et al. [37] found evidence of fishpond density as a major risk factor for malaria transmission.

Wells or excavation sites are common in rural Nariño, in the southwest of the country. Nearly all houses have one as a source of water for domestic purposes. The main malaria vector species in this area, An. albimanus and $A n$. calderoni, were associated with this type of larval habitat. Wells have been recognized as suitable larval habitats for mosquitoes, including as a refuge during the dry season for Anopheles, Aedes and Culex species [38], and treatment using larvivorous fish in wells has been associated with a reduction in malaria transmission [39].

One of the limitations of this study is related to its design. This was a cross sectional study where every larval habitat was sampled only once. This information provided a general overview of the characteristics of larval habitats present in a great variety of malaria-endemic localities. However data collected are insufficient neither to carry out a more specialized analysis nor to estimate possible associations between larval habitats, seasonality nor climate. 


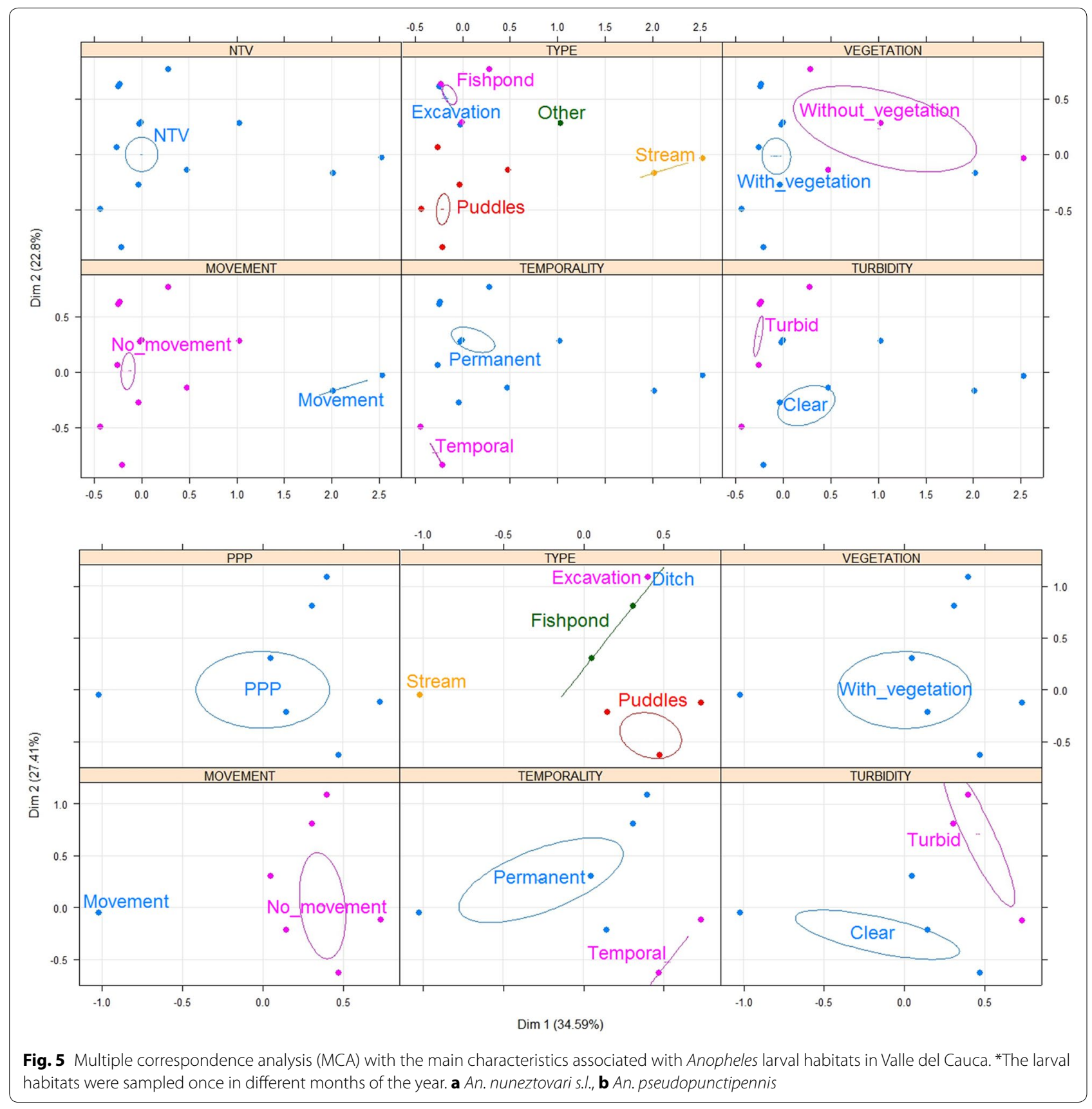

Given that the most common larval habitats of the main malaria vector species in two sites were humanmade and permanent water bodies (fishponds and wells), which people use for economic activities (fish rearing) or provision of water for domestic purposes, these habitats cannot be eliminated but could and should be treated. Different possibilities could be explored avoiding any harm to the reared fish or the humans who may consume the water, particularly that from wells or excavation sites.
Anopheles albimanus larvae were found in the three states, principally associated to larval habitats with standing water and the presence of vegetation. This species was associated with permanent larval habitats with turbid water in Córdoba, as in other parts of Latin America [24, 30-42]. The results showed that An. albimanus exploits a wide variety of larval habitats, including fishponds, lagoon, puddles, ditches, and excavation sites [41-48], which would make control of this species difficult and could favour high densities of adult mosquitoes 


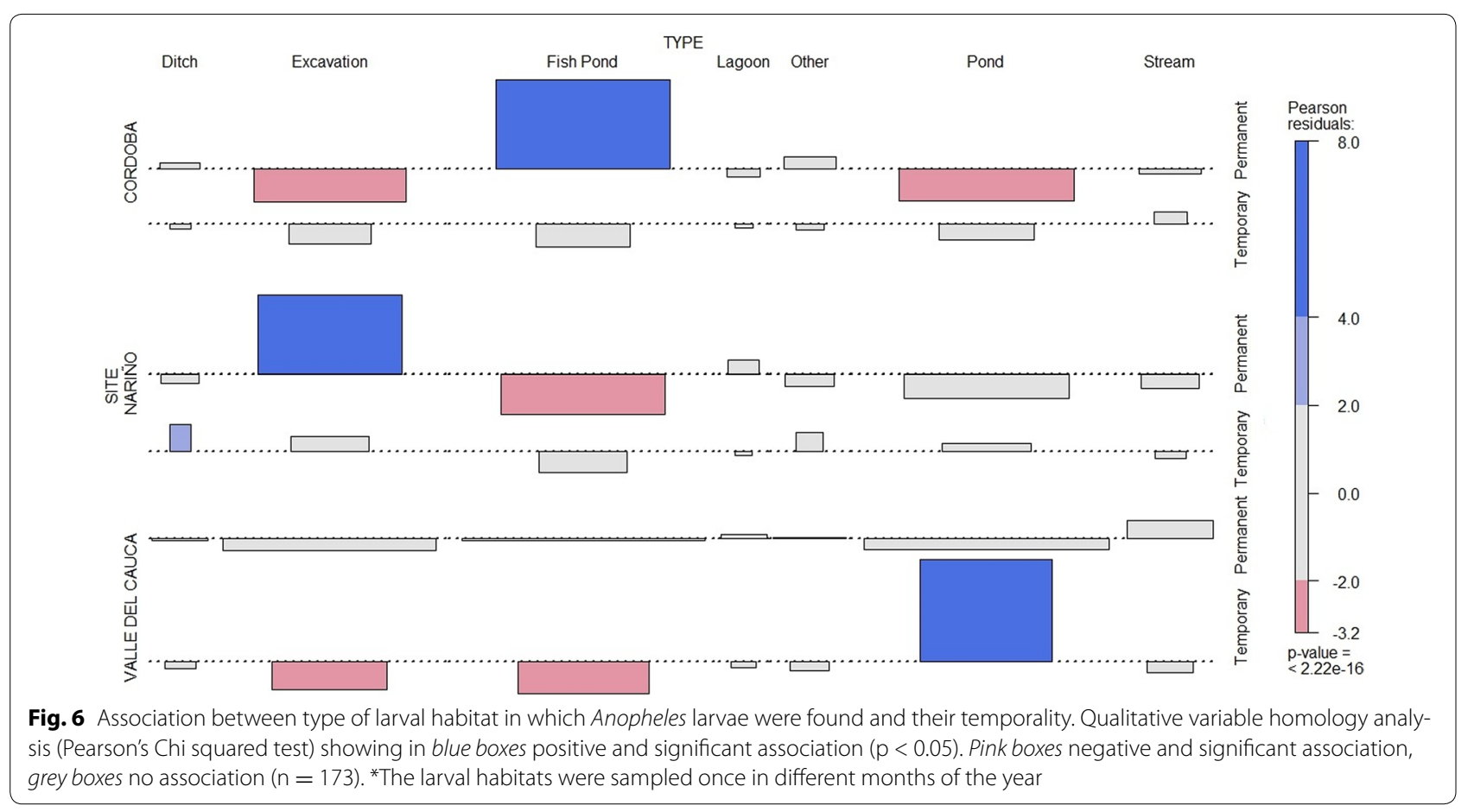

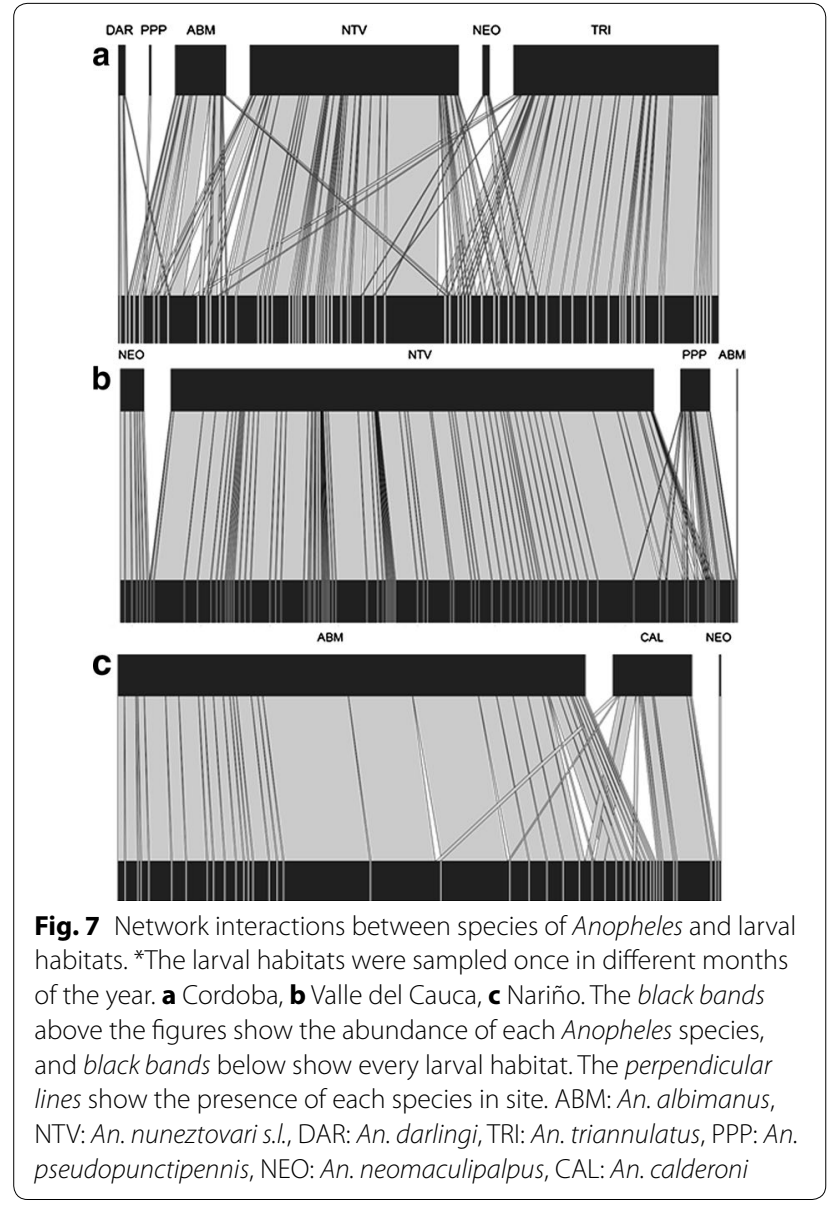

in its distribution range. According to the results of the MCA, association of An. albimanus with certain types of larval habitats was only statistically significant in Nariño where this species was found mainly associated with puddles without any use and excavation sites used for domestic purposes. In this study, An. albimanus was found sharing larval habitats with An. calderoni, An. neomaculipalpus, An. pseudopunctipennis, An. nuneztovari s.l., An. darlingi, and An. triannulatus, which indicates its plasticity [42-49].

Little was known regarding the characteristics of $A n$. calderoni larval habitats. According to Wilkerson [50], larvae of this species are found mainly in small streams, small irrigation canals and swamps, mostly in dense emergent vegetation. In this study, An. calderoni was associated mainly with human-made wells or excavation sites with standing water used for domestic activities.

Larvae of An. nuneztovari s.l. were present more often in habitats with clear stagnant water characterized by having vegetation [51, 52]. This species was related to permanent habitats in Córdoba, but to temporary ones in Valle del Cauca, showing that An. nuneztovari s.l. can be present in larval habitats regardless of their temporality [52-54]. Although An. nuneztovari s.l. was collected with other species, such as An. albimanus, An. darlingi, An. pseudopunctipennis, An. triannulatus, and An. neomaculipalpus [36, 51, 55-58], the affinity index was significant only with An. neomaculipalpus in Cordoba. In this study, An. nuneztovari s.l. was collected in excavation sites, 
Table 4 Fager's affinity index between Anopheles species in the study area during 2011-2012

\begin{tabular}{|c|c|c|c|c|c|c|}
\hline Córdoba & $A B M$ & DAR & NEO & NTV & PPP & TRI \\
\hline $\mathrm{ABM}$ & - & -0.15 & -0.15 & 0.27 & 0.15 & 0.07 \\
\hline DAR & & - & -0.22 & -0.08 & -0.35 & -0.08 \\
\hline NEO & & & - & 0.67 & -0.22 & 0.14 \\
\hline NTV & & & & - & 0.08 & 0.25 \\
\hline PPP & & & & & - & -0.08 \\
\hline TRI & & & & & & - \\
\hline Nariño & ABM & CAL & NEO & & & \\
\hline $\mathrm{ABM}$ & - & 0.16 & -0.09 & & & \\
\hline CAL & & - & -0.14 & & & \\
\hline NEO & & & - & & & \\
\hline Valle del Cauca & $A B M$ & NEO & NTV & PPP & & \\
\hline $\mathrm{ABM}$ & - & -0.19 & -0.06 & -0.13 & & \\
\hline NEO & & - & -0.01 & -0.13 & & \\
\hline NTV & & & - & 0.27 & & \\
\hline PPP & & & & - & & \\
\hline
\end{tabular}

ABM: An. albimanus, NTV: An. nuneztovari s.l., DAR: An. darlingi, TRI: An. triannulatus, PPP: An. pseudopunctipennis, NEO: An. neomaculipalpus, CAL: An. calderoni The larval habitats were sampled once in different months of the year. Indexes $>0.5$ means association between the different anopheline species occurring in the same larval habitat [31]

Table 5 Average distance between negative and positive larval habitats and the nearest house in the states of Cordoba, Nariño and Valle del Cauca (2011-2012)

\begin{tabular}{|c|c|c|c|c|c|c|}
\hline SITE (n) & $\begin{array}{l}\text { Sampled larval habitats } \\
\text { Mean (SD) }\end{array}$ & $\begin{array}{l}\text { Positive larval habitats } \\
\text { Mean (SD) }\end{array}$ & $\begin{array}{l}\text { Negative larval habitats } \\
\text { Mean (SD) }\end{array}$ & df & $\mathbf{F}$ & $p$ value \\
\hline Córdoba (172) & $56.3(56.3)$ & $57.2(52.4)$ & $55.8(58.7)$ & $1 ; 170$ & 0.25 & 0.874 \\
\hline Nariño (221) & $20.12(32.7)$ & $22.7(35.0)$ & $19.5(32.3)$ & $1 ; 219$ & 0.31 & 0.578 \\
\hline Valle del Cauca (699) & $143.2(183.7)$ & $205.7(21.9)$ & $136.8(179.6)$ & $1 ; 697$ & 5.93 & $0.015^{* *}$ \\
\hline
\end{tabular}

ANOVA $(a=0.05)$

$S D$ standard deviation, $d f$ degrees of freedom

The larval habitats were sampled once in different months of the year

** Significant $p<0.05$

fishponds, lagoons, streams, puddles, and ditches but the MCA results did not show an association between the species and any particular larval habitat type. This may reflect the availability of possible sites more than a particular species preference for any larval habitat type.

A clear association was observed between An. triannulatus larvae and standing water in fishponds surrounded by vegetation. These results contradict those found in Amazonian Brazil [59], Chiapas in Mexico [45] and Perú [56] where this species showed a more generalist habitat colonization and exploited larval habitats such as lakes, streams with slow currents, slow-moving rivers, large ponds, mining excavation sites, ditches, or marshes. This is the first time this species is found associated with standing and muddy water. Anopheles triannulatus was found sharing larval habitats with An. albimanus, $A n$. darlingi, An. neomaculipalpus, An. nuneztovari s.l., and
An. pseudopunctipennis $[49,51,53,54,57-61]$. However, the affinity index for An. triannulatus was not significant for any combination of species.

The presence of larval habitats near houses has been found to be associated with abundance of mosquito larvae [62] and malaria transmission risk [63], mainly in Africa. However, in this study, Anopheles-positive larval habitats were found further from the nearest house compared to Anopheles-negative larval habitats. This difference was only significant for the temporary puddles in Valle del Cauca in which Anopheles-negative larval habitats were significantly closer to houses compared to Anopheles-positive larval habitats. It is important these results be considered by the malaria programme since potential larval habitats closer to houses might be easier to treat, whereas more distant ones might remain untreated. 


\section{Conclusions}

This study of larval habitats provides information relevant to malaria programmes. In the context of Latin America malaria control or elimination programmes, other control measures are necessary beyond indoor targeting of adult mosquitoes, such as LLINs or IRS. Treatment of larval habitats may be an appropriate complementary option since the main larval habitats found were human-made (permanent fishponds and wells or excavation sites), well defined, and feasible to control. Local evaluation of larval control strategies should be implemented and evaluated.

\begin{abstract}
Abbreviations
Bsph: Bacillus sphaericus; Bti: Bacillus thurigiensis variety israelensis; EMMIE: malaria elimination in Mesoamerica and Hispaniola; $H^{\prime}$ : Shannon diversity index; IGAC: Instituto Geográfico Agustin Codazzi; IRS: indoor residual spraying; LLINs: long-lasting insecticide-rreated mosquito nets; MCA: multiple correspondence analysis; WHO: World Health Organization.
\end{abstract}

\section{Authors' contributions}

MC participated in the data analysis and drafted the manuscript. PXP participated in the determination of specimens and drafted the manuscript. LIO participated in drafting the manuscript. MLA and PP participated in the selection of the localities and coordination of the fieldwork. SD, JAJ and BAC participated in the data analysis. SH was involved during the project conception and reviewed the manuscript. MLQ and JCB contributed to the project concept, design of the study and participated in writing the manuscript. All authors read and approved the final manuscript.

\section{Author details}

${ }^{1}$ Departamento de Salud Pública, Facultad de Medicina, Universidad Nacional de Colombia, Bogotá, DC, Colombia. ${ }^{2}$ Grupo de Entomología Instituto Nacional de Salud, Bogotá, DC, Colombia. ${ }^{3}$ Departamento de Estadistica, Facultad de Ciencias, Universidad Nacional de Colombia, Bogota, DC, Colombia. ${ }^{4}$ Laboratorio de Salud Pùblica, Instituto Departamental de Salud de Nariño, Nariño, Colombia. ${ }^{5}$ Department of Public Health Sciences, University of Miami Miller School of Medicine, Miami, FL, USA. ${ }^{6}$ Caucaseco Scientific Research Centre/Immunology Institute, Universidad Del Valle, Cali, Colombia.

\section{Acknowledgements}

We are grateful to the community members who allowed us to work in their localities during the breeding site sampling. We thank the biologists, Diana Cabarcas, Eliana Galindo and Ivonni Avila who coordinated the fieldwork and their field assistants in each area, and Amy Krystosik for a critical review of the manuscript. This project was funded by the NIAID ICEMR (research Grant U19AI089802) and Colciencias (research Grant 360-2011). The funders had no role in study design, data collection or analysis, decision to publish, or preparation of the manuscript.

\section{Competing interests}

The authors declare that they have no competing interests.

Received: 28 August 2015 Accepted: 19 November 2015 Published online: 01 December 2015

\section{References}

1. WHO. World malaria report. 2014. Geneva: World Health Organization. 2014. http://www.who.int/malaria/publications. Accessed 26 Jan 2015.

2. Herrera S, Ochoa-Orozco SA, González IJ, Peinado L, Quiñones ML, Arévalo-Herrera M. Prospects for malaria elimination in Mesoamerica and Hispaniola. PLoS NegI Trop Dis. 2015;9:e0003700. doi:10.1371/journal. pntd.0003700.
3. Villelabeitia I. Ten countries rally to eliminate malaria in Central America and the Caribbean. 2013. http://www.theglobalfund.org/en/mediacenter/newsreleases/2013-06-28_Ten_Countries_Rally_to_Eliminate_ Malaria_in_Central_America_and_the_Caribbean/. Accessed 13 Feb 2015.

4. The Global Health Group and the Malaria Atlas Project. 2011. Atlas of malaria-eliminating countries, 2011. http://www.malariaeliminationgroup.org/sites/default/files/atlas/global/Global-Atlas-2011.pdf. Accessed 11 Feb 2015.

5. Durnez L, Coosemans M. Residual transmission of malaria: An old issue for new approaches. In: Manguin S, editor. Anopheles mosquitoes—new insights into malaria vectors, Chapter 21. 2013. http://www.intechopen. com/books/anopheles-mosquitoes-new-insights-into-malaria-vectors/ residual-transmission-of-malaria-an-old-issue-for-new-approaches.

6. Montoya-Lerma J, Solarte YA, Giraldo-Calderon GI, Quiñones ML, RuizLopez F, González R. Malaria vector species in Colombia-a review. Mem Inst Oswaldo Cruz. 2011;106(suppl 1):223-38.

7. Olano VA, Brochero HL, Sáenz R, Quiñones ML, Molina JA. Mapas preliminares de la distribución de especies de Anopheles vectores de malaria en Colombia. Biomédica. 2001;21:402-8.

8. Orjuela LI, Ahumada ML, Avila I, Herrera S, Beier JC, Quiñones ML. Human biting activity, spatial-temporal distribution and malaria vector role of Anopheles calderoni in the southwest of Colombia. Malar J. 2015;14:256.

9. Quiñones ML, Ruiz F, Calle DA, Harbach RE, Linton YM. Incrimination of Anopheles (Nyssorhynchus) rangeli and An. (Nys.) oswaldoi as natural vectors of Plasmodium vivax in Southern Colombia. Mem Inst Oswaldo Cruz. 2006;101:617-23.

10. Quiñones M, Suarez M, Rodríguez A, Fleming GA, Galvis LE. Comportamiento de Anopheles (Kerteszia) lepidotus Zavortink, 1973 y su discriminación como posible vector de malaria en el departamento del Tolima Colombia. Biomedica. 1984;1:5-13.

11. Escovar JE, González R, Quiñones ML. Anthropophilic biting behaviour of Anopheles (Kerteszia) neivai Howard, Dyar and Knab associated with Fishermen's activities in a malaria-endemic area in the Colombian Pacific. Mem Inst Oswaldo Cruz. 2013;108:1057-64.

12. Escovar JE, González R, Quiñones ML, Wilkerson RC, Ruiz F, Harrison BA. Morphology of the larvae, male genitalia and DNA sequences of Anopheles (Kerteszia) pholidotus (Diptera: Culicidae) from Colombia. Mem Inst Oswaldo Cruz. 2014;109:473-9.

13. Conn J, Norris D, Donnelly MJ, Beebe NW, Burkot TR, Coulibaly MB, et al. Entomological monitoring and evaluation: diverse transmission settings of ICEMR projects will require local and regional malaria elimination strategies. Am J Trop Med Hyg. 2015;93:28-41.

14. Killeen GF. Characterizing, controlling and eliminating residual malaria transmission. Malar J. 2014;13:330.

15. WHO. The role of larviciding for malaria control in sub-Saharan Africa. World Health Organization. Global Malaria Programme, Geneva. http:// www.who.int/malaria/publications/atoz/interim_position_statement_ larviciding_sub_saharan_africa.pdf?ua=1 Document WHO. Geneva, Switzerland. Accessed 21 Feb 2015.

16. WHO. Larval source management: a supplementary measure for malaria vector control: an operational manual. Geneva: World Health Organization; 2013.

17. Fillinger U, Lindsay SW. Suppression of exposure to malaria vectors by an order of magnitude using microbial larvicides in rural Kenya. Trop Med Int Health. 2006;11:1629-42.

18. Nartey R, Owusu-Dabo E, Kruppa T, Baffour-Awuah S, Annan A, Oppong $\mathrm{S}$, et al. Use of Bacillus thuringiensis var israelensis as a viable option in an Integrated Malaria Vector Control Programme in the Kumasi Metropolis, Ghana. Parasit Vectors. 2013;6:172.

19. Berti J, Herrera M, González J, Puentes N, Caraballo R, Valero J. Field trials on the efficacy and persistence of three formulations of Bacillus sphaericus against larvae of Anopheles aquasalis Curry in mangroves of Mariño municipality, Sucre state, Venezuela. Boletin de Malariologia y Salud Ambiental. 2012;52:67-77.

20. Rojas W, Northup J, Gallo O, Montoya AE, Montoya F, Restrepo M, et al. Reduction of malaria prevalence after introduction of Romanomermis culicivorax (Mermithidae: Nematoda) in larval Anopheles habitats in Colombia. Bull World Health Organ. 1987;65:331-7.

21. Tusting LS, Thwing J, Sinclair D, Fillinger U, Gimnig J, Bonner KE, et al. Mosquito larval source management for controlling malaria. Cochrane Database Syst Rev. 2013;8:CD008923. 
22. Walshe DP, Garner P, Abdel-Hameed AA, Pyke GH, Burkot T. Larvivorous fish for preventing malaria transmission - a review. Cochrane Database Syst Rev. 2013;12:CD008090.

23. Mohamed AA. Study of larvivorous fish for malaria vector control in Somalia, 2002. East Mediterr Health J. 2003;9:618-26.

24. Rubio-Palis Y. Anopheles (Nyssorhynchus) de Venezuela. Taxonomía, Bionomía, Ecología e Importancia Médica. Publicado por la escuela de malariología y sanemaiemto ambiental "Dr. Arnoldo Gabaldón" y el proyecto control de enfermedades endémicas. Maracay, Venezuela. 2000. pp 120.

25. Padilla JC, Álvarez G, Montoya R, Chaparro P, Herrera S. Epidemiology and control of malaria in Colombia. Mem Inst Oswaldo Cruz. 2011;106(Suppl 1):114-22.

26. Porras A, Galindo JI, Pimentel JP, Herrera A, Carrasquilla G. Frequency and tendency of malaria in Colombia, 1990 to 2011: a descriptive study. Malar J. 2014;13:202. doi:10.1186/1475-2875-13-202.

27. IGAC, Instituto Geográfico Agustín Codazzi. Diccionario Geográfico de Colombia. Tercera edición. Bogotá: Instituto Geográfico Agustín Codazzi. 1996.

28. Service MW. Mosquito ecology: field sampling methods. Chapman and Hall, 2nd edn. Elsevier Science Publishers, Essex, UK. 1993.

29. Belkin J, Schick R, Galindo P, Aitken T. Estudios sobre mosquitos (Diptera: Culicidae). Un proyecto para un estudio sistemático de los mosquitos de mesoamérica. Ila. Métodos para coleccionar, criar y preservar mosquitos. Contrib Am Entomol Inst. 1967;1:163-80.

30. González R, Carrejo N. Introducción al estudio taxonómico de Anopheles de Colombia claves y notas de distribución. 2nd ed. Cali: Programa Editorial de la Universidad del Valle; 2009.

31. Fager EW, McGowan JA. Zooplankton species groups in the North Pacific. Science. 1963;140:453-61.

32. Shannon CE. A mathematical theory of communication. Bell Sys Tech J. 1948;27:379-423.

33. Vittor AY, Gilman RH, Tielsch J, Glass G, Shields T, Lozano WS, et al. The effect of deforestation on the human-biting rate of Anopheles darlingi, the primary vector of Falciparum malaria in the Peruvian Amazon. Am J Trop Med Hyg. 2006;74:3-11.

34. Costa KM, De Almeida WA, Magalhaes IB, Montoya R, Moura MS, De Lacerda MV. Malaria in Cruzeiro do Sul (Western Brazilian Amazon): analysis of the historical series from 1998 to 2008. Rev Panam Salud Publica. 2010;28:353-60

35. Saraiva MGG, Amorim RDS, Moura MAS, Martinez-Espinosa FE, Barbosa MGV. Expansão urbana e distribuição espacial da malária no município de Manaus, Estado do Amazonas. Rev Soc Bras de Med Trop. 2009;42:515-22.

36. Tadei WP, Thatcher BD, Santos JM, Scarpassa VM, Rodrigues IB, Rafael MS. Ecologic observations on anopheline vectors of malaria in the Brazilian Amazon. Am J Trop Med Hyg. 1998;59:325-35.

37. Maheu-Giroux M, Casapia M, Soto-Calle VE, Ford LB, Buckeridge $\mathrm{DL}$, Coomes OT, et al. Risk of malaria transmission from fishponds in the Peruvian Amazon. Acta Trop. 2010;115:112-8. doi:10.1016/j. actatropica.2010.02.011

38. Govoetchan R, Gnanguènon V, Ogouwalé E, Oké-Agbo F, Azondékon R, Sovi $A$, et al. Dry season refugia for anopheline larvae and mapping of the seasonal distribution in mosquito larval habitats in Kandi, northeastern Benin. Parasit Vectors. 2014;7:137.

39. Ghosh SK, Tiwari SN, Sathyanarayan TS, Sampath TR, Sharma VP, Nanda N, et al. Larvivorous fish in wells target the malaria vector sibling species of the Anopheles culicifacies complex in villages in Karnataka, India. Trans R Soc Trop Med Hyg. 2005;99:101-5.

40. Rojas E, Velásquez J, Rosas C, Villegas E, Perez H, Rosario C, et al. Mesofauna de criaderos naturales de Anopheles spp y las poblaciones depredadoras de sus larvas. Bol Dir Malaríol San Amb. 1998;38:63-7.

41. Pinault LL, Hunter FF. Characterization of larval habitats of Anopheles albimanus, Anopheles pseudopunctipennis, Anopheles punctimacula, and Anopheles oswaldoi s.l. populations in lowland and highland Ecuador. J Vector Ecol. 2012:37:124-36

42. Herrera-Varela M, Orjuela LI, Peñalver C, Conn JE, Quiñones ML. Anopheles species composition explains differences in Plasmodium transmission in La Guajira, northern Colombia. Mem Inst Oswaldo Cruz. 2014;109:955-9.
43. Forattini OP. Entomología médica vol I. Facultade de Higiene e Saúde Pública S Paulo. 1962

44. Faran ME. A revision of the Albimanus section of the subgenus Nyssorhynchus of Anopheles. Contrib Am Entomol Inst. 1980;15:1-215.

45. Rejmánková E, Savage H, Rejmanek M, Roberts DR, Arredondo-Jimenez J. Multivariate analysis of relationships between habitats, environmental factors and occurrence of anopheline mosquito larvae (Anopheles albimanus, An. pseudopunctipennis) in southern Chiapas, Mexico. J Appl Ecol. 1991;28:827-41.

46. Rejmankova E, Roberts DR, Harbach RE, Pecor J, Peyton EL, Manguin S, et al. Environmental and regional determinants of Anopheles (Diptera: Culicidae) larval distribution in Belize. Central America. Environ Entomol. 1995;22:978-92.

47. Roberts DR, Manguin S, Rejmankova E, Andre R, Harbach RE, Vanzie E, et al. Spatial distribution of adult Anopheles darlingi and Anopheles albimanus in relation to riparian habitats in Belize. Central America. J Vector Ecol. 2002;27:21-30.

48. Guthmann JP, Llanos-Cuentas A, Palacios A, Hall AJ. Environmental factors as determinants of malaria risk: a descriptive study on the northern coast of Peru. Trop Med Int Health. 2002;7:518-25.

49. Brown R, Scorza JV. Faunula culicida en un área del estado de Trujillo, Venezuela, y su importancia vectora. Bol Dir Malariol San Amb. 1995;35:25-9.

50. Wilkerson RC. Anopheles (Anopheles) calderoni n. sp., a malaria vector of the Arribalzagia series from Peru (Diptera: Culicidae). Mosquito Syst. 1991;23:25-38.

51. Brochero H, Pareja PX, Ortiz G, Olano VA. Sitios de cría y actividad de picadura de especies de Anopheles en el municipio de Cimitarra, Santander, Colombia. Biomédica. 2006;26:269-77.

52. Parra-Henao G, Alarcón EP. Observaciones sobre la bionomía de Anopheles spp. (Diptera: Culicidae) en el municipio Valencia, departamento Córdoba. Colombia. Bol Dir Malariol San Amb. 2008:48:95-8.

53. Rubio-Palis Y. Vector biology and malaria transmission in western Venezuela. PhD Thesis, university of London. 1991. pp 261.

54. Rojas E, Brown E, Rosas C, Scorza JV. Populations of larvae of Anopheles spp. in natural larval habitats in Western Venezuela, an area of refractory malaria. Rev Saúde Pública. 1992;26:336-42. doi:10.1590/ S0034-89101992000500007.

55. Nagm L, Luitgards-moura JF, Neucamp CDS, Monteiro-de-barros FS, Honório NA, Tsouris P, et al. Affinity and diversity indices for anopheline immature forms. Inst Med Trop S Paulo. 2007;49:309-16.

56. Hayes J, Calderón G, Falcon R, Zambrano V. Newly incriminated anopheline vectors of human malaria parasites in Junin Department, Perú. J Amer Mosq Control Assoc. 1987;3:418-22.

57. Gutierrez LA, González JJ, Gomez GF, Castro MI, Rosero DA, Luckhart $S$, et al. Species composition and natural infectivity of anthropophilic Anopheles (Diptera: Culicidae) in the states of Córdoba and Antioquia, Northwestern Colombia. Mem Inst Oswaldo Cruz. 2009;104:1117-24.

58. Rejmánková E, Rubio-Palis Y, Villegas L. Larval habitats of Anopheline mosquitoes in the Upper Orinoco, Venezuela. J Vector Ecol. 1999;24:130-7.

59. McKeon SN, Schlichting CD, Povoa MM, Conn JE. Ecological suitability and spatial distribution of five Anopheles species in Amazonian Brazil. Am J Trop Med Hyg. 2013;88:1079-86. doi:10.4269/ajtmh.12-0203.

60. Faran ME, Linthicum KJ. A handbook of the Amazonian species of Anopheles (Nyssorhynchus) (Diptera: Culicidae). Mosq Syst. 1981;13:1-81.

61. Berti J, Vanegas C, Amarista J, González J, Montañez H, Castillo M, et al. Inventario preliminar y observaciones biológicas sobre los Anophelinos (Diptera:Culicidae) de una región minera del estado Bolivar, Venezuela. Bol Entomol Venez. 1998;13:17-26.

62. Kweka EJ, Zhou G, Munga S, Lee MC, Atieli HE, Nyindo M, et al. Anopheline larval habitats seasonality and species distribution: a prerequisite for effective targeted larval habitats control programmes. PLoS One. 2012;7:e52084. doi:10.1371/journal.pone.0052084.

63. Nixon CP, Nixon CE, Arsyad DS, Chand K, Yudhaputri FA, Sumarto W, et al. Distance to Anopheles sundaicus larval habitats dominant among risk factors for parasitemia in meso-endemic Southwest Sumba, Indonesia. Pathog Glob Health. 2014;108:369-80. 